\title{
Sequence of Workable Days for Mechanized Harvest of Sugarcane in Southern Brazil
}

\author{
Luciano H. S. Vieira ${ }^{1}$, Paulo C. Sentelhas ${ }^{1}$ \& André B. Pereira ${ }^{2}$ \\ ${ }^{1}$ Agricultural College "Luiz de Queiroz", University of São Paulo, Piracicaba, SP, Brazil \\ ${ }^{2}$ State University of Ponta Grossa, Ponta Grossa, PR, Brazil \\ Correspondence: Paulo C. Sentelhas, Department of Biosystems Engineering, Agricultural College "Luiz de \\ Queiroz" (ESALQ), University of São Paulo, Av. Pádua Dias, 11, 13418-900 Piracicaba, SP, Brazil. Tel: \\ 55-193-429-4283. E-mail: pcsentel.esalq@usp.br
}

Received: February 9, 2019 Accepted: March 10, $2019 \quad$ Online Published: May 15, 2019

doi:10.5539/jas.v11n6p199 URL: https://doi.org/10.5539/jas.v11n6p199

\begin{abstract}
The probabilities of workable days (WD), as well as probability of having a given sequence of days for sugarcane mechanized harvest in Southern Brazil is a very useful information for planning of such operation. Thus, the aim of this study was to determine the simple and conditional probabilities of WD for the abovementioned field operation in the State of São Paulo, Brazil, by means of the Markov Chain, to define the probabilities of sequences of WD. The number of WD (NWD) was determined for 32 years for ten sites using as criteria soil water holding capacity of $40 \mathrm{~mm}$, rainfall $\leq 3 \mathrm{~mm}$ and relative soil water storage $\leq 90 \%$. Based on NWD dataset, the simple probabilities of WD and non-workable (NW) days, as well as the conditional probabilities were determined. Finally, the probability of sequences of WD per ten-day period was obtained by the Markov chain. The results showed that Western, Northwestern and Northern, on average, were more likely to have WD compared to Southern and Eastern regions of the state. In addition, the most likely periods of WD were between April and September, being the first ten-day period of July the one with the highest possible probability $(\geq 90 \%)$. The probability of having a workable day given that the previous day was workable always remained at a minimum of roughly $50 \%$ along with a maximum close to $90 \%$ at all assessed sites. Finally, the probability of a sequence of eight or more WD per ten-day period was always below $40 \%$ along the year, showing that is difficult to have such a long period available for planning sugarcane mechanized harvest in the assessed locations. Therefore, we recommend that fleets sizing should be defined as a function of NWD in conjunction with the probability of the sequence of WD at a given ten-day period.
\end{abstract}

Keywords: Harvest planning, rainfall, simple and conditional probabilities, trafficability

\section{Introduction}

Field agricultural operations are highly dependent on local meteorological conditions along with soil moisture, which define whether a given operation might be adopted or not at a given specific-site (Monteiro et al., 2014). One of the ways of determining the probability of the sequence of suitable days for a particular field operation based on weather conditions is by means of a method known as Markov chain (Mandal et al., 2015; Sanchez-Cohen et al., 2015; Manikandan et al., 2017; Griffin et al., 2017). According to Bonini (2004), Markov chain considers a basic principle that the probability of a given day to depict a particular status depends on the status of the previous day. This might be applied to situations that are governed by the rainfall regime as a conditioning variable, since its occurrence at a given day will impinge upon soil water conditions for several days (Cadena-Zapata et al., 2002; Obour et al., 2017).

In most of the studies reported in the literature, first and second order Markov chains have been largely used all over the world (Griffin et al., 2017). Nevertheless, the use of Markov chains of an order greater than two is of a great importance because at certain specific-sites occurrences of rainfall at one day might be conditionally dependent on the sequence of dry and rainy days throughout several previous days (Sonnadara \& Jayewardene, 2015; Yang et al., 2016; Carvalho et al., 2017). This might happen, for instance, in regions where at certain stages of the crop growing season occurrences of a large number of consecutive days with rainfall or a long series of dry days are frequent (Keller Filho et al., 2006). 
In pioneer researches, Gabriel and Neumann (1962), and Weiss (1964) made use of homogeneous Markov chains to describe the high persistence of consecutive dry days in Israel and United States, respectively. Another pivotal work was the one published by Stern and Coe (1982), which proposed a simulation model for daily precipitation based on the occurrence of rainfall generated from Markov chain, as well as on the amount of rainfall generated by a gamma distribution approach. In the sequence, several authors have been using the Markov chain approach for different purposes in hydrology (Yang et al., 2016; Sonnadara \& Jayewardene, 2015) and precision agriculture (Monteiro et al., 2014; Sanchez-Cohen et al., 2015; Mandal et al., 2015; Manikandan et al., 2017; Griffin et al., 2017).

With regards to the usage of Markov chain to assess the probabilities of suitable days for field work with agricultural machinery at a given site, Ataíde et al. (2012) observed that this approach was efficient and conducive to consistent results for such a purpose. Monteiro et al. (2014), researching the number of workable days for the soil management as a function of rainfall regime along with soil water availability at different specific-sites in Brazil, determined the conditional probabilities of consecutive days suitable for mechanized activities by means of Markov chain at each ten-day period throughout the year. They concluded that the utilization of Markov chain for a study of such a nature is an important tool for planning periods more appropriate to machinery for soil preparation and management in order to help size fleets.

Bearing in mind the importance of determining the occurring probability of workable days, as well as occurring probability of a given sequence of these days for the mechanized harvest of sugarcane in the State of São Paulo, Brazil, Markov chain technique turns out to be a fundamental tool for the planning of this particular agricultural practice, which, therefore, comprises since the number of agricultural implements to be acquired by growers up to the planning of final costs related to this operation in the field. In view of such a problem, the aim of the current study was to apply the Markov chain technique for determining both simple and conditional probabilities of workable days' occurrence, as well as probabilities of sequences of workable days for the mechanized harvest of sugarcane at ten different producing-regions located in the State of São Paulo, Brazil.

\section{Material and Methods}

\subsection{Studied Sites and Field Data}

This study was carried out at ten specific-sites belonging to the major producing-regions of sugarcane located in the State of São Paulo, Brazil, which are discriminated in Table 1 and Figure 1. For such sites, daily meteorological datasets for a series of 32 years (1982-2013) were collected from the website of DAEE/SP for daily rainfall amounts, as well as from the NASA/POWER system for daily minimum and maximum temperatures, mean relative humidity, global solar radiation, and wind speed. Data provided by the NASA/POWER system were employed for estimating reference evapotranspiration (ETo) in accordance with the Penman-Monteith approach (Allen et al., 1998). ETo and rainfall data were utilized in the making of daily sequential water balances (WBSeq) based on the method proposed by Thornthwaite and Mather (1955) at each specific-site taking into consideration soil water holding capacities (SWHC) of 40 and $80 \mathrm{~mm}$. Such water balances were used to define SM/SWHC for each day of the year.

Table 1. Representative specific-sites from the producing-areas of sugarcane for the evaluation of occurring probabilities of sequence of workable days for mechanized harvest of sugarcane in the State of São Paulo, Brazil by means of the Markov chain

\begin{tabular}{lllll}
\hline ID & Site & Latitude & Longitude & Altitude (m) \\
\hline 1 & Araçatuba & $21^{\circ} 13^{\prime} 44^{\prime \prime}$ & $50^{\circ} 46^{\prime} 32^{\prime \prime}$ & 320 \\
2 & Dois Córregos & $22^{\circ} 22^{\prime} 00^{\prime \prime}$ & $48^{\circ} 23^{\prime} 00^{\prime \prime}$ & 719 \\
3 & Andradina & $20^{\circ} 55^{\prime} 00^{\prime \prime}$ & $51^{\circ} 22^{\prime} 00^{\prime \prime}$ & 370 \\
4 & Ipaussu & $23^{\circ} 01^{\prime} 45^{\prime \prime}$ & $49^{\circ} 34^{\prime} 05^{\prime \prime}$ & 624 \\
5 & Ituverava & $20^{\circ} 20^{\prime} 00^{\prime \prime}$ & $47^{\circ} 46^{\prime} 00^{\prime \prime}$ & 578 \\
6 & Paraguaçu Paulista & $22^{\circ} 25^{\prime} 15^{\prime \prime}$ & $50^{\circ} 34^{\prime} 16^{\prime \prime}$ & 491 \\
7 & Pradópolis & $21^{\circ} 21^{\prime} 48^{\prime \prime}$ & $48^{\circ} 03^{\prime} 51^{\prime \prime}$ & 540 \\
8 & Piracicaba & $22^{\circ} 48^{\prime} 03^{\prime \prime}$ & $47^{\circ} 39^{\prime} 45^{\prime \prime}$ & 591 \\
9 & Potirendaba & $21^{\circ} 02^{\prime} 37^{\prime \prime}$ & $49^{\circ} 22^{\prime} 29^{\prime \prime}$ & 489 \\
10 & Cardoso & $20^{\circ} 08^{\prime} 00^{\prime \prime}$ & $49^{\circ} 58^{\prime} 00^{\prime \prime}$ & 420 \\
\hline
\end{tabular}




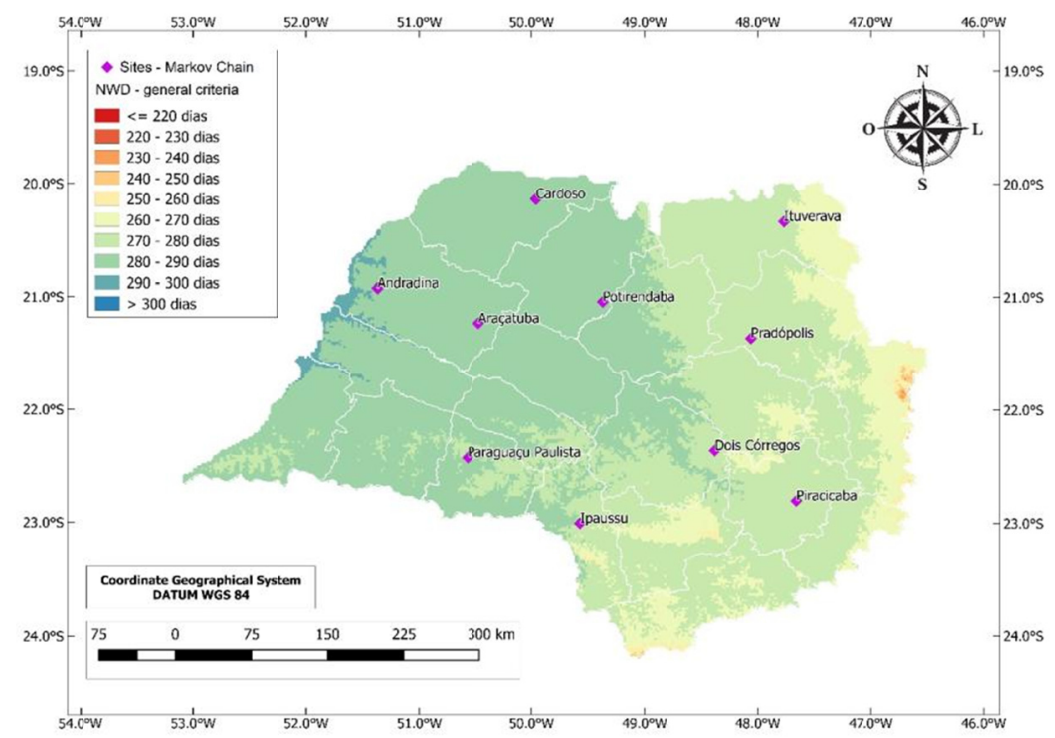

Figure 1. Sites in which the number of workable days (NWD) and the probabilities of sequence of workable days for mechanized harvest of sugarcane were determined in the State of São Paulo, Brazil

\subsection{Simple and Conditional Probabilities of Workable Days}

SWHC, rainfall (PREC) and SM/SWHC data were employed for the definition of the number of workable days for the mechanized harvest of sugarcane (NWD) by means of the general criteria in accordance with the assumption that a given day was considered to be workable under the following conditions: AWC of $40 \mathrm{~mm}$, PREC $<3 \mathrm{~mm}$, and SM/AWC $<90 \%$ (40-03-90) (Vieira, 2017). Thus, for each one of the ten sites and 36 ten-day periods of the year the number of workable (W) and non-workable (NW) days were defined and used for defining the simple probabilities of one day to be classified as workable $(\mathrm{P}(\mathrm{W}))$ or non-workable $(\mathrm{P}(\mathrm{NW}))$. Taking into account the number of $\mathrm{W}$ and $\mathrm{NW}$ days, conditional probabilities for one single day to be considered as $\mathrm{W}$ given that the previous day was $\mathrm{W}(\mathrm{P}(\mathrm{W} \mid \mathrm{W}))$, $\mathrm{W}$ once the previous day was ascribed as $\mathrm{NW}(\mathrm{P}(\mathrm{W} \mid \mathrm{NW}))$, NW as the previous day was $\mathrm{W}(\mathrm{P}(\mathrm{NW} \mid \mathrm{W}))$ and $\mathrm{NW}$ when the previous day was $\mathrm{NW}(\mathrm{P}(\mathrm{NW} \mid \mathrm{NW}))$ were also determined (Table 2).

Table 2. Matrix of first order for analysis of conditional probabilities of workable (W) and non-workable (NW) days by means of the Markov chain

\begin{tabular}{lll}
\hline \multirow{2}{*}{ Current day } & \multicolumn{2}{c}{ Previous day } \\
\cline { 2 - 3 } & $\mathrm{W}$ condition & $\mathrm{NW}$ condition \\
\hline W condition & $\mathrm{P}(\mathrm{W} \mid \mathrm{W})$ & $\mathrm{P}(\mathrm{W} \mid \mathrm{NW})$ \\
$\mathrm{NW}$ condition & $\mathrm{P}(\mathrm{NW} \mid \mathrm{W})$ & $\mathrm{P}(\mathrm{NW} \mid \mathrm{NW})$ \\
\hline
\end{tabular}

For calculation of the conditional probabilities obtained by means of the Markov chain the following equations were taken into consideration (Ataíde et al., 2012; Monteiro et al., 2014):

$$
\begin{gathered}
P(W \mid W)=\frac{N(W \mid W)}{N(W \mid W)+N(N W \mid W)}=\frac{N(W \mid W)}{N(W)} \\
P(N T \mid T)=\frac{N(N W \mid W)}{N(W \mid W)+N(N W \mid W)}=\frac{N(N W \mid W)}{N(W)}=1-P(W \mid W) \\
P(N W \mid N W)=\frac{N(N W \mid N W)}{N(W \mid N W)+N(N W \mid N W)}=\frac{N(N W \mid N W)}{N(N W)} \\
P(W \mid N W)=\frac{N(W \mid N W)}{N(W \mid N W)+N(N W \mid N W)}=\frac{N(W \mid N W)}{N(N W)}=1-P(N W \mid N W)
\end{gathered}
$$

where, $\mathrm{N}(\mathrm{W} / \mathrm{W})$ is the number of workable days given that the previous day was also workable; $\mathrm{N}(\mathrm{W} / \mathrm{NW})$ is the number of workable days given that the previous day was non-workable; $\mathrm{N}(\mathrm{NW} / \mathrm{NW})$ is the number of non-workable days on which the previous day was also non-workable; $\mathrm{N}(\mathrm{W})$ is the total number of workable days; $\mathrm{N}(\mathrm{NW})$ is the total number of non-workable days. 


\subsection{Sequential Probabilities of Workable Days}

Shortly after calculation of the conditional probabilities a geometrical equation (Equation 5), which is a function of the conditional probability obtained by means of the Markov chain, was employed for the estimation of mean sequential probabilities of workable days at each ten-day period of the year as proposed by Robertson (1976):

$$
\mathrm{P}(\mathrm{n})=\mathrm{P}(\mathrm{W}) \times \mathrm{P}(\mathrm{W} \mid \mathrm{W})^{\mathrm{n}-1}
$$

where, $\mathrm{P}(\mathrm{n})$ is the occurring probability of " $\mathrm{n}$ " workable consecutive days for the mechanized harvest of sugarcane.

\section{Results and Discussion}

Figures 2 to 6 show both simple and conditional probabilities along with probabilities of sequences of one to ten workable days for the ten sites under scrutiny. By analyzing Figures 2 to 6 as to simple and conditional probabilities, it is possible to verify that for all assessed sites the period with the highest probability of workable days for sugarcane mechanized harvest is the one comprised between the third ten-day period of April and the first ten-day period of September. However, on the third ten-day period a systematical drop-probability of workable days was observed in all sites, except in Ipaussu (Figures 5C and 5D) and Paraguaçu Paulista (Figures 6A and 6B). In these two sites, the drop occurs on the second ten-day period of May. This might be explained due to the occurrence of cold fronts coming from the South, which firstly reach Southern Brazil and Vale do Paranapanema, heading afterwards to other regions of the State of São Paulo, promoting rainfalls shortly after its passage and, hence, increasing soil water moisture (Monteiro, 1964).

In the regions encompassing West, Northwest and North of the State, the occurring probabilities of workable days are higher than those ones related to the South, where Ipaussu (Figures 5C and 5D ) and Paraguaçu Paulista (Figures 6A and 6B) are located. Another aspect to be borne in mind is that in Ituverava (Figures 2A and 2B), Potirendaba (Figures 3C and 3D), Pradópolis (Figure 4A and 4B) and Dois Córregos (Figures 4C and 4D), the probability of workable days is equal to the probability of non-workable days throughout the two quintessential months of the summer time in Brazil (January and February), whereas at other sites the probability of non-workable days is slightly higher as opposed to the probability of workable days. Such information is pivotal in order to plan sowing operation in sugarcane production fields throughout this particular season of the year, since for the planting practice it is necessary to realize the harvest of seedlings (Fernandes, 2011).

Monteiro et al. (2014) obtained results from trials carried out in Piracicaba whose probabilities of days favorable to soil management practices vary from $66.6 \%$ on the first ten-day period of April to $14.1 \%$ on the third ten-day period of August, whist annual average of these probabilities was of $43.1 \%$ in conjunction with a standard deviation of $12.7 \%$. The results reported by the aforementioned authors revealed lower probabilities in comparison to the outcomes found in the current study for the same location; however, field operations assessed were quite distinct, once in this particular work harvest operation was evaluated taking into account that such an operation might take place in wetter soils, as well as in drier soils as opposed to agricultural management practices linked to soil tillage.

By scrutinizing the sequential probabilities of one to ten consecutive workable days throughout periods with the highest probabilities, comprising, therefore, the end of April up until the beginning of September, Ipaussu (Figures $5 \mathrm{C}$ and 5D) turns out to be the site with the lowest probabilities. For such a site, a sequence of ten workable days possesses a minimum probability of about $4 \%$ and a maximum probability lower than $20 \%$. Even under the consideration of a sequence of just one workable day, chances are that there might be a minimum probability of $75 \%$ on the third ten-day period of May and a maximum probability of roughly $91 \%$. Yet taking into account the probability of one workable day, we observed that at none of the sites assessed in the current study a $100 \%$ probability is to be possible, whose maximum probability found was of around $95 \%$ at the sites of Araçatuba (Figures 3A and 3B), Potirendaba (Figures 3C and 3D) and Pradópolis (Figures 4A and 4B). 

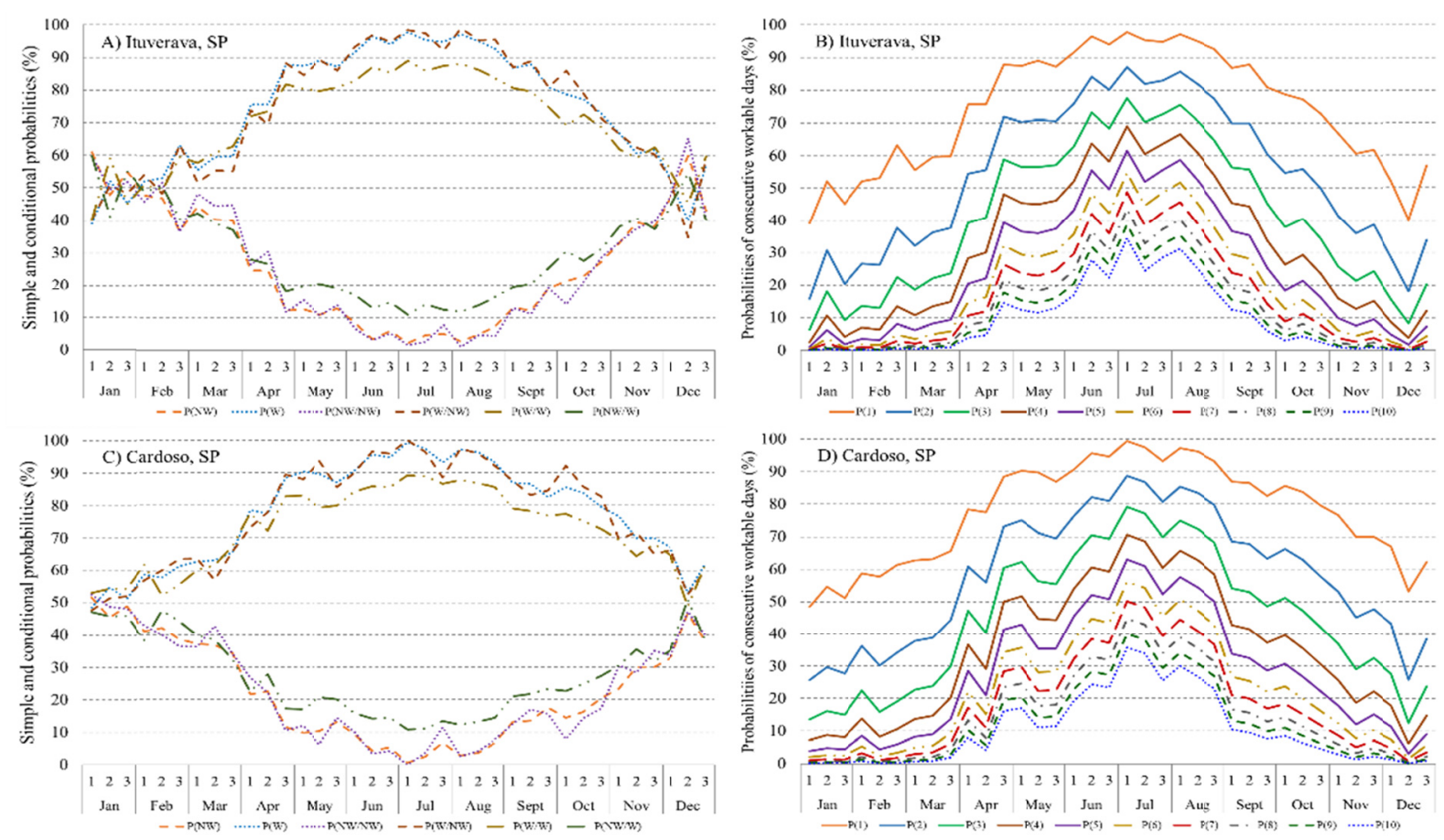

Figure 2. Simple and conditional probabilities of workable (W) and non-workable (NW) days (A, C), as well as sequential probability of one $(\mathrm{P}(1))$ to ten $(\mathrm{P}(10))$ consecutive workable days $(\mathrm{B}, \mathrm{D})$ for the mechanized harvest of sugarcane in Ituverava and Cardoso, SP, Brazil
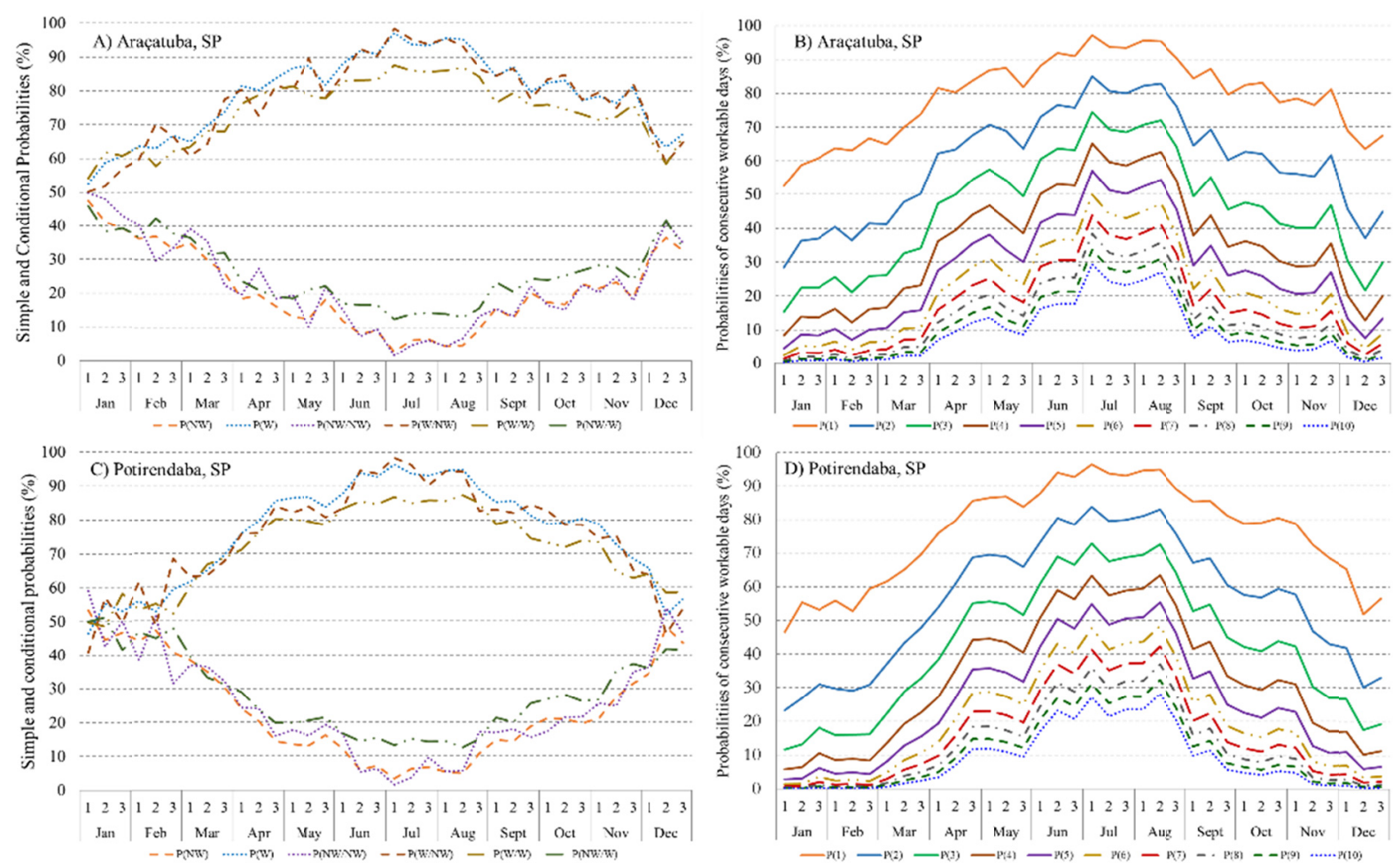

Figure 3. Simple and conditional probabilities of workable (W) and non-workable (NW) days (A, C), as well as sequential probability of one $(\mathrm{P}(1))$ to ten $(\mathrm{P}(10))$ consecutive workable days $(\mathrm{B}, \mathrm{D})$ for the mechanized harvest of sugarcane in Araçatuba and Potirendaba, SP, Brazil 

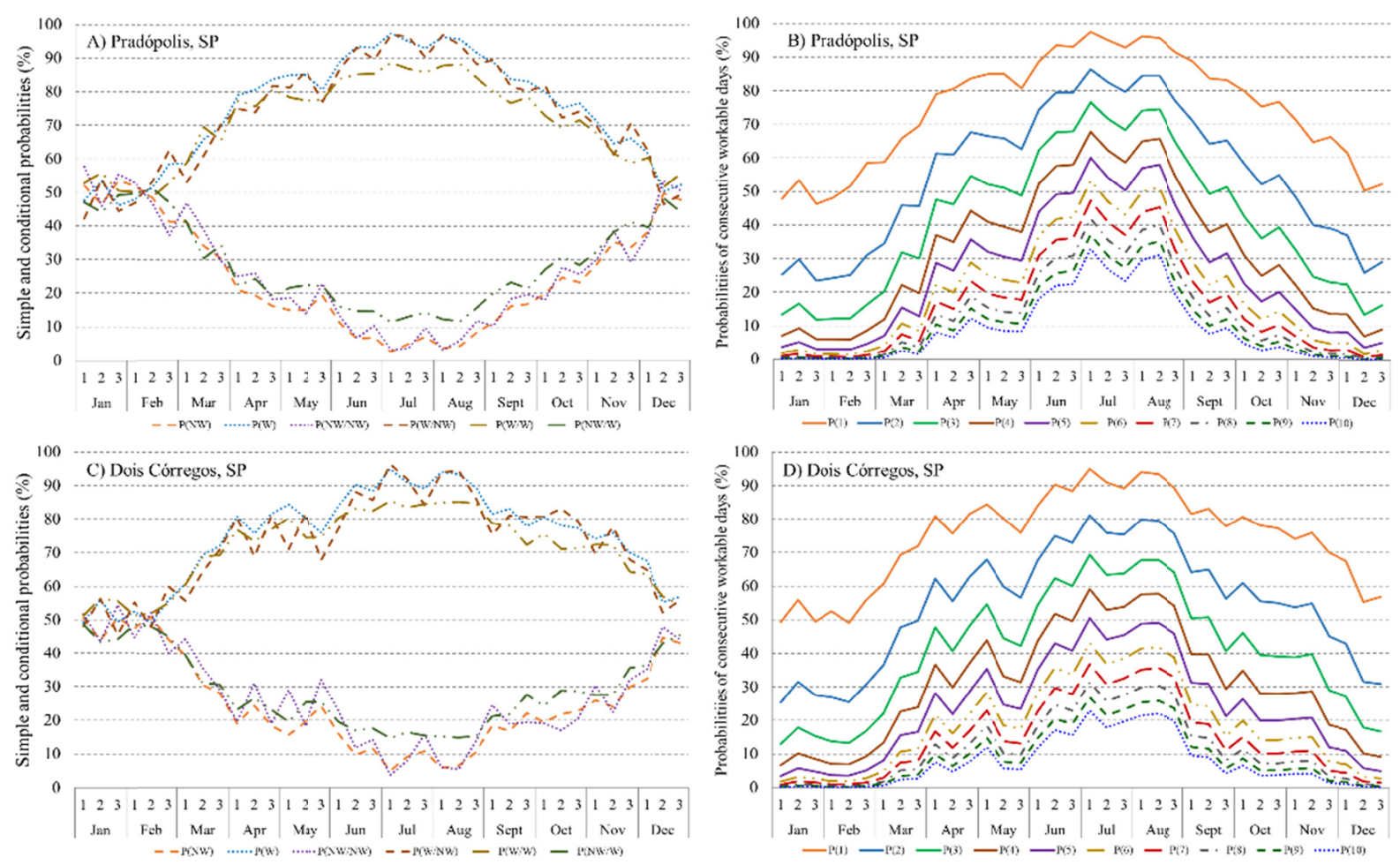

Figure 4. Simple and conditional probabilities of workable (W) and non-workable (NW) days (A, C), as well as sequential probability of one $(\mathrm{P}(1))$ to ten $(\mathrm{P}(10))$ consecutive workable days $(\mathrm{B}, \mathrm{D})$ for the mechanized harvest of sugarcane in Pradópolis and Dois Córregos, SP, Brazil
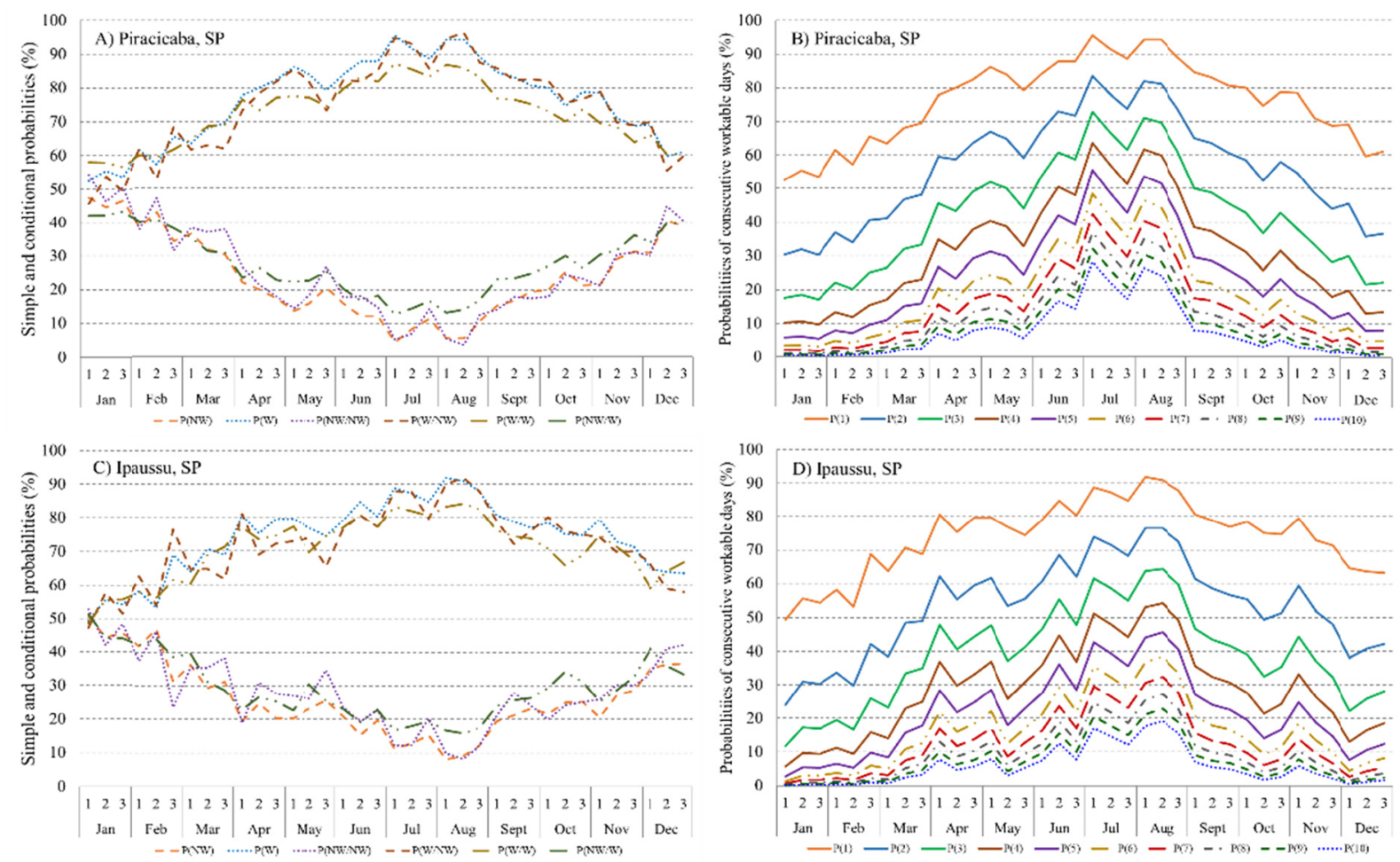

Figure 5. Simple and conditional probabilities of workable (W) and non-workable (NW) days (A, C), as well as sequential probability of one $(\mathrm{P}(1))$ to ten $(\mathrm{P}(10))$ consecutive workable days $(\mathrm{B}, \mathrm{D})$ for the mechanized harvest of sugarcane in Piracicaba and Ipaussu, SP, Brazil 

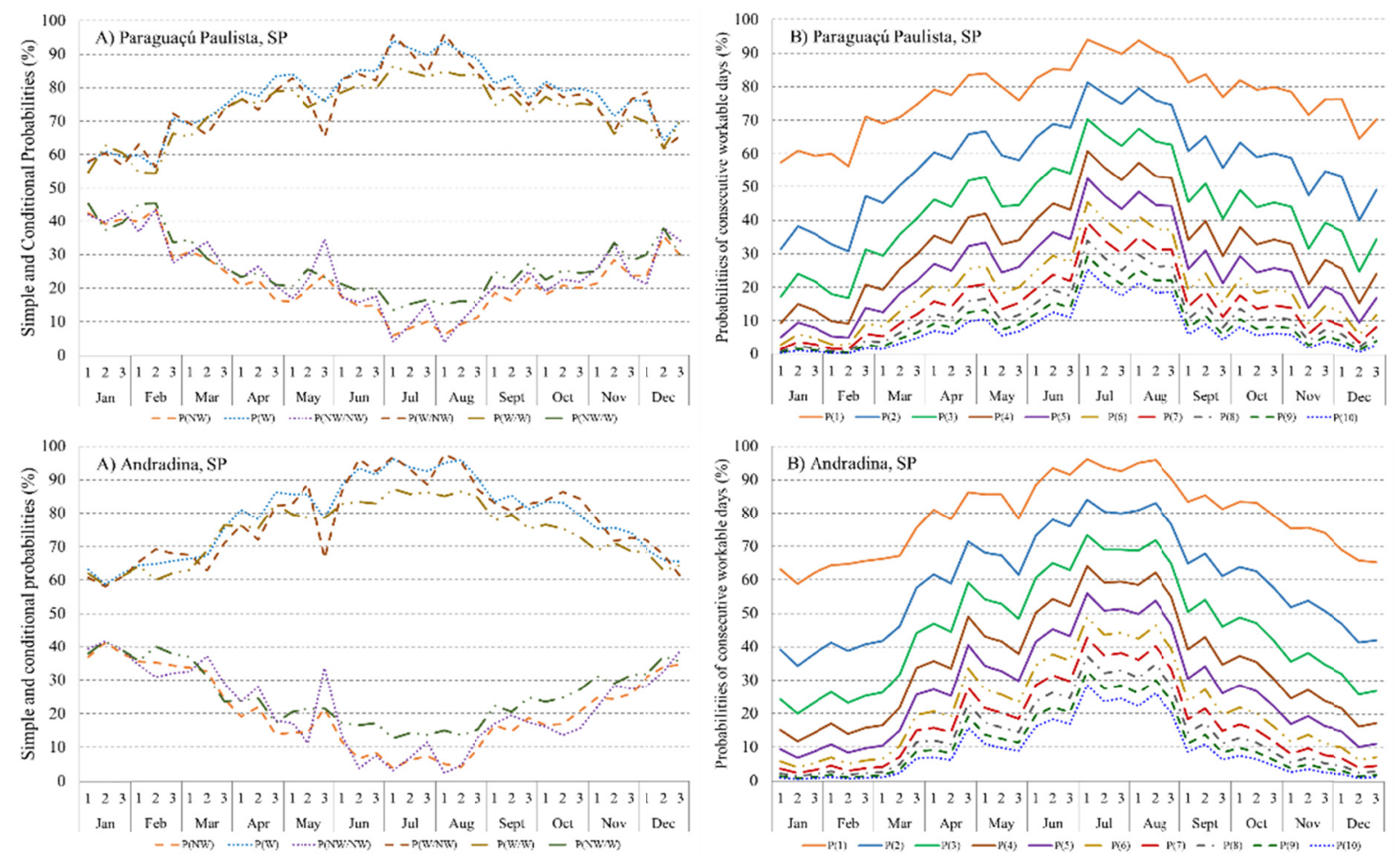

Figure 6. Simple and conditional probabilities of workable (W) and non-workable (NW) days (A, C), as well as sequential probability of one $(\mathrm{P}(1))$ to ten $(\mathrm{P}(10))$ consecutive workable days $(\mathrm{B}, \mathrm{D})$ for the mechanized harvest of sugarcane in Paraguaçú Paulista and Andradina, SP, Brazil

For all evaluated cases, a rise of one single day on the sequence of consecutive workable days tends to reduce almost to a half the probability of such a sequence throughout the months comprised between January and March. This percentage of drop diminishes insofar as months of winter approach and spring and summer return to intensify. For Araçatuba (Figures 3A and 3B), October and November are the months with sequential probability values of consecutive workable days far close, ranging from $5 \%$ for a sequence of ten workable days to $78 \%$ for a sequence of just one workable day. Moreover, it can be noticed that on the third ten-day period of November there was a consistent rise in probability. Such a fact is vital to be considered to provide planning of grinding at this site, once it might be established a longer period of harvest in this case as opposed to other regions under scrutiny.

Still by scrutinizing Figures 2 through 6, it is noticeable that there is an accentuated drop of the sequential probabilities of workable days on the first ten-day period of September at Araçatuba (Figures 3A and 3B), Potirendaba (Figures 3C and 3D), Piracicaba (Figures 5A and 5B) and Ipaussu (Figures 5C and 5D). Furthermore, for Pradópolis (Figures $4 \mathrm{~A}$ and $4 \mathrm{~B}$ ) such a fact occurs on the second ten-day period of the same month. At other sites however, such as Dois Córregos (Figures 4C and 4D), Paraguaçu Paulista (Figures 6A and 6B) and Andradina (Figures 6C and 6D), the aforementioned probability-drop occurs on both the first and third ten-day period of September.

Carvalho et al. (2009), examining occurring probabilities of dry periods in the municipality of Rio Largo, AL, Brazil, made use of a series of 30 years of daily rainfall data (1973-2002) and, therefore, established the dry period as the one of sequence of dry days throughout which the minimum amount of daily rainfall was lower than 0.85 $\mathrm{mm}$. Statistical analyses were performed by means of the Instat Climatic Software and dry periods were defined for three distinct intervals ( $\geq 5$ days, $\geq 7$ days and $\geq 10$ days). Out of the three dry periods scrutinized the one of five days demonstrated the highest occurring probability (varying from 10 to $40 \%$ ) for all years. March turned out to be the month with an occurring probability of five-day dry periods of $90 \%$, being among months associated with the highest occurring probabilities (March to August), whereas June and July showed, respectively, probabilities of 30 and $20 \%$. The probability of occurring a dry period ranging from five to seven days is of $20 \%$, corresponding to six years; varying from five to ten days is of $30 \%$ (nine years); and remaining within the range of seven to ten days is of $10 \%$ (three years). Such outcomes evidence the impact of different climatic conditions that prevailed in the State of São Paulo, once harvest of sugarcane in Alagoas starts only when it finishes in the Southeast. With 
regards to occurrence of dry periods of five days, we observed that in São Paulo the probability of having a sequence of five workable days is lower and falls between 40 and $60 \%$ (Figures 2 to 6 ).

Results obtained by Ataíde et al. (2012), by evaluating probabilities of suitable days for field work with agricultural machinery by means of Markov chain, indicated that the best period for performing cultural management practices at an external environment in Londrina, PR, comprises from April to September, with an optimum between the end of July and beginning of September. Such results corroborate those outcomes obtained in the current work concerning a period with the highest possible probability of workable days comprising between April and September. Nevertheless, the month with the highest probability found in this particular study differs from Ataíde et al. (2012) owing to the fact that it focusses on the first ten-day period of July rather than on the end of July and beginning of September, as preconized by the aforementioned authors. In addition, according to these authors such probabilities provided the possibility of determining needs of machinery to performing mechanized agricultural practices in the field.

Estrada et al. (2015) concluded that the highest occurring probability of favorable days for work with agricultural machinery in Santa Maria, located further South of the State of Rio Grande do Sul in comparison to occurring probabilities of favorable days for trafficability in Passo Fundo, might be ascribed to soil hydric-physical attributes. According to Kaufmann et al. (2012), in typical predominant latosols of Passo Fundo, alterations on soil water availability might be intensified by a dispersion of clay on the surface. Release of clay reduces dimension of soil canaliculus by illuviation of thin particles, bringing about a sealing on soil surface (Lima Neto et al., 2010). In this particular research, soil physical attributes were not directly examined; however, the criteria established for determination of workable days employed soil hydric-physical characteristics by means of the ratio SM/SWHC, bearing in mind that such a parameter in conjunction with precipitation are responsible for substantial fluctuations in occurring probabilities of workable days as thoroughly described by Estrada et al. (2015).

Ataíde et al. (2012), by analyzing the probabilities of suitable days for field work with agricultural machinery, reached the conclusion that there is a strong dependence relationship between current trafficability and immediately precedent trafficability conditions indicating that a given workable day is greatly influenced by the previous favorable day and vice-versa. In this specific study, the authors obtained analogous outcomes so that the probability of a day to be considered as a workable day given that the previous day was workable always remained at a minimum of roughly $50 \%$ probability along with a maximum close to $90 \%$ at all sites under scrutiny (Figures 2 to 6$)$.

Sequences of workable and non-workable periods are necessary for successful agricultural crop planning and soil and water conservation measures. Chances of occurrence of consecutive workable periods throughout the year indicate how many days are suitable for field operations, such as soil preparation, sowing, harvesting, chemicals application and other agricultural management practices in order to be conducive to a more rational estimation of the number of agricultural machines required for fleet's sizing. As observed in our study and others around the world, Markov chain has been showing satisfactory results as an indicator of periods with the highest occurrence chances of favorable events for field work on the basis of daily climatological series of rainfall and soil moisture status.

\section{Conclusions}

The current study was conducted to define the probability of a sequence of consecutive WD for mechanized sugarcane harvest. The outcomes evidenced that the NWD varied among regions and from season to season, as well as in compliance with the sequence of a given number of WD per ten-day period. In general, the probability of one WD per ten-day period reached always a minimum of roughly $50 \%$, whereas the probability of a sequence of eight or more WD per ten-day period was always below $40 \%$ throughout the year. The findings obtained emphasize the importance of considering the available WD for fleets sizing and field operations planning, such as sugarcane mechanized harvest under soil and climate conditions of Brazil.

\section{References}

Allen, R. G., Pereira, L. S., Raes, D., \& Smith, D. M. (1998). Crop evapotranspiration: Guidelines for computing crop water requirements (p. 297). Rome: FAO.

Ataíde, L. T., Caramori, P. H., Ricce, W. S., Silva, D. A. B., \& Souza, J. R. P. (2012). The probability of potentially useful work days during the year in Londrina. Semina-Ciências Agrárias, 33(6), 2215-2226. https://doi.org/10.5433/1679-0359.2012v33n6p2215 
Bonini, A. S. S. (2004). Aplicação do método cadeia de Markov à ocorrência de temperatura mínima do ar no estado do Rio Grande do Sul (p. 113, Dissertação (Mestrado em Meteorologia), Universidade Federal de Pelotas, Pelotas).

Carvalho, A. L., Souza, J. L., Lyra, G. B., Porfirio, A. C. S., Ferreira Junior, R. A., Santos, M. A., \& Wanderley, H. S. (2009). Probabilidade de ocorrência de períodos secos para a região de Rio Largo, Alagoas. XVI Congresso Brasileiro de Agrometeorologia, Belo Horizonte, MG.

Carvalho, A. L., Souza, J. L., Lyra, G. B., Porfirio, A. C. S., Ferreira Junior, R. A., Santos, M. A., \& Wanderley, H. S. (2017). Markov chain application for dry and rainy days. Revista Brasileira de Meteorologia, 32(2), 207-214. https://doi.org/10.1590/0102-77863220001

Cadena-Zapata, M., Hoogmoed, W. B., \& Perdok, U. D. (2002). Field studies to assess the workable range of soils in the tropical zone of Veracruz, Mexico. Soil \& Tillage Research, 68, 83-92. https://doi.org/10.1016/ S0167-1987(02)00112-5

Estrada, J. S., Schlosser, J. F., Farias, M. S., Santos, G. O., \& Rüdell, I. Y. P. (2015). Metodologia para estimar o número de dias trabalháveis com máquinas agrícolas. Revista Ceres, 62(4), 410-414. https://doi.org/10.1590/ 0034-737X201562040011

Fernandes, A. C. (2011). Cálculos na Agroindústria da Cana-de-Açúcar (3rd ed., p. 416).

Gabriel, K. R., \& Neumann, J. (1962). A Markov chain model for daily rainfall occurrence at Tel Aviv. Quarterly Journal of the Royal Meteorological Society, 88, 90-95. https://doi.org/10.1002/qj.49708837511

Griffin, T. W., Miller, N. J., Bergtold, J., Shanoyan, A., Sharda, A., \& Ciampitti, I. A. (2017). Farm's sequence of adoption of information intensive precision agricultural technology. Applied Engineering in Agriculture, 33(4), 521-527. https://doi.org/10.13031/aea.12228

Keller Filho, T., Zullo Junior, J., \& Lima, P. R. S. R. (2006). Análise da transição entre dias secos e chuvosos por meio da cadeia de Markov de terceira ordem. Pesquisa Agropecuária Brasileira, 41(9), 1341-1349. https://doi.org/10.1590/S0100-204X2006000900001

Kaufmann, V., Castro, N. M. R., \& Pinheiro, A. (2012). Escoamentos superficiais e de drenagem em solo com diferentes manejos e intensidades de chuvas simuladas. Revista Brasileira de Recursos Hídricos, 17(4), 273-285. https://doi.org/10.21168/rbrh.v17n4.p273-285

Lima Neto, J. A., Ribeiro, M. R., Corrêa, M. M., Souza Júnior, V. S. S., Araújo Filho, J. C., \& Lima, J. F. (2010). Atributos químicos, mineralógicos e micromorfológicos de horizontes coesos de latossolos e argissolos dos tabuleiros costeiros do estado de Alagoas. Revista Brasileira de Ciência do Solo, 34(2), 473-486. https://doi.org/10.1590/S0100-06832010000200021

Mandal, K. G., Padhi, J., Kumar, A., Ghosh, S., Panda, D. K., Mohanty, R. K., \& Raychaudhuri, M. (2015). Analyses of rainfall using probability distribution and Markov chain models for crop planning in Daspalla region in Odisha, India. Theoretical Applied Climatology, 121(3-4), 521-527. https://doi.org/10.1007/ s00704-014-1259-z

Manikandan, M., Thiyagarajan, G., Bhuvaneswari, J., \& Prabhakaran, N. K. (2017). Wet and dry spell analysis for agricultural crop planning using Markov chain probability model at Bhavanisagar. International Journal of Mathematics and Computer Applications Research, 7(1), 11-22.

Monteiro, C. A. F. (1964). Sobre um índice de participação das massas de ar e suas possibilidades de aplicação à classificação climática. Revista Geográfica, 33(61), 59-69.

Monteiro, L. A., Sentelhas, P. C., \& Piedade, S. M. S. (2014). Dias trabalháveis para o manejo do solo em função da chuva e da disponibilidade hídrica do solo em diferentes regiões brasileiras. Revista Ambiente \& Água, 9(3), 459-475. https://doi.org/10.4136/ambi-agua.1389

Obour, P. B., Lamandé, M., Edwards, G., Sorensen, C. G., \& Munkholm, L. J. (2017). Predicting soil workability and fragmentation in tillage: A review. Soil Use and Management, 33(2), 288-298. https://doi.org/10.1111/ sum. 12340

Robertson, G. W. (1976). Dry and wet spells (p. 28). Malaysia: Project Field Report.

Sanchez-Cohen, I., Diaz-Padilla, G., Velasquez-Valle, M., Slack, D. C., Heilman, P., \& Pedroza-Sandoval, A. (2015). A decision support system for rainfed agricultural areas of Mexico. Computers and Electronics in Agriculture, 114, 178-188. https://doi.org/10.1016/j.compag.2015.03.009 
Sonnadara, U. J., \& Jayewardene, D. R. (2015). A Markov chain probability model to describe wet and dry patterns of weather at Colombo. Theoretical Applied Climatology, 119, 333-340. https://doi.org/10.1007/ s00704-014-1117-z

Stern, R. D., \& Coe, R. (1982). The use of rainfall models in agricultural planning. Agricultural Meteorology, 26(1), 35-50. https://doi.org/10.1016/0002-1571(82)90056-5

Thornthwaite, C. W., \& Mather, J. R. (1955). The water balance (p. 104, Publications in Climatology, Vol. VIII, No. 1). Centerton, NJ: Drexel Institute of Technology, Laboratory of Climatology.

Vieira, L. H. S. (2017). Dias trabalháveis para a colheita mecanizada da cana-de-açúcar no estado de São Paulo, com base em critérios agrometeorológicos (p. 144, Tese (Doutorado em Ciências), ESALQ/Universidade de São Paulo, Piracicaba).

Weiss, L. L. (1964). Sequence of wet or dry days described by a Markov chain probability model. Monthly Weather Review, 92(4), 169-176. https://doi.org/10.1175/1520-0493(1964)092<0169:SOWODD>2.3.CO:2

Yang, J., Wang, Y., Chang, J., Yao, J., \& Huang, Q. (2016). Integrated assessment for hydrometeorological drought based on Markov chain model. Natural Hazards, 84, 1137-1160. https://doi.org/10.1007/s11069016-2480-0

\section{Copyrights}

Copyright for this article is retained by the author(s), with first publication rights granted to the journal.

This is an open-access article distributed under the terms and conditions of the Creative Commons Attribution license (http://creativecommons.org/licenses/by/4.0/). 